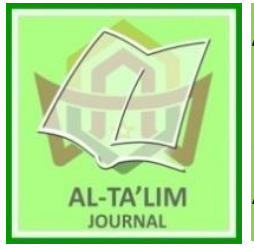

AL-TA'LIM JOURNAL, 28 (1), 2021, (55-66)

(Print ISSN 1410-7546 Online ISSN 2355-7893)

Available online at http://journal.tarbiyahiainib.ac.id/index.php/attalim

\title{
Integrating Science and Religion at Malaysian and Indonesian Higher Education
}

Received: $13^{\text {th }}$ September 2020; Revised: $17^{\text {th }}$ February 2021; Accepted: $28^{\text {th }}$ February 2021

Permalink/DOI: http://dx.doi.org/10.15548/jt.v28i1.658

\section{Mohammad Hidayaturrahman* \\ Universitas Wiraraja Madura, Indonesia. \\ E-mail: hidayaturrahman@wiraraja.ac.id}

\section{Sudarman}

Universitas Islam Negeri Imam Bonjol

Padang, Indonesia.

E-mail: sudarmanma@uinib.ac.id

\section{Husamah}

Universitas Muhammadiyah Malang, Indonesia.

E-mail: usya bio@umm.ac.id

\section{Ita Rahmania Kusumawati}

Universitas Hasyim Asy’ari Jombang, Indonesia.

E-mail: ita.jombang@yahoo.com

\begin{abstract}
This article analyzes the integration model between science and religion in Malaysian and Indonesian Higher Education. So far, the dichotomy of science and religion is considered to be one of the causes for the exit of the Islamic world from the Western world. In this century, educational institutions in the Islamic world began to re-select the integration pattern of science. This study uses qualitative methods, by collecting data through observation, visiting two higher education institutions studied, and conducting in-depth interviews with relevant parties, namely the International Islamic University Malaysia (IIUM) in Malaysia and Universitas Muhammadiyah Malang (UMM) in Indonesia. Data collection is also done by searching documents and referral sources in various data sources available online. From the research conducted, it was found that, integration carried out by Islamic universities in Malaysia and Indonesia was to open faculties and study programs without any religious or public claims. Everything is the same, and there are no restrictions on the rules for students based on religion to enter into it. So, education is inclusive, it can be for anyone. This model succeeded in advancing Islamic educational institutions.
\end{abstract}

\section{*) Corresponding Author}

Keywords: Southeast Asia; educational integration; inclusive Islamic education.

How to Cite: Hidayaturrahman, M., Sudarman, S., Husamah, H., \& Kusumawati, I. (2021). Integrating Science and Religion at Malaysian and Indonesian Higher Education. Al-Ta lim Journal, 28(1). doi:https://doi.org/10.15548/jt.v28i1.658

\section{INTRODUCTION}

In history, the dichotomy of science itself has taken place (Dahlberg, 2013; Putnam, 1966). This condition has an impact and is the cause of the prolonged decline of Muslims in the field of science, which has been going on since the 16th century to the 17 th century. The century was known as the century of stagnation in Islamic thought (Ahmed \& Segerson, 2006; Dallal, 2018; Sing, 2017), while in the western world it is known as the age of enlightenment and the rise of science. The dichotomy of Islamic sciences and general sciences is also caused by the existence of Western colonialism over Islamic countries, especially from the 18th century to the 19th century. Islamic countries are unable to resist the efforts made by the West, especially the injection of culture and civilization. This dichotomy in its continuation has a negative impact on the progress of Islam (Maussen et al., 2011; Tan, 2017; Umar, 2005; Wallerstein, 1999). 
The dichotomy of science and religion is found in the work of previous scientists, such as al-Ghazali, who divided science into two; syar'iyyah science (Sharia science) and ghayru syar'iyyah science (non-sharia science). The same thing also happened to Ibn Khaldun who divided his knowledge into al'ulum al naqliyah (knowledge sourced from the arguments of the Qur'an and the Hadith of the Prophet SAW) and al-ulum al-'aqliyah (science based on reason and rationality). In the midst of the dichotomy, scientists were still born who mastered various fields of science, including Ibn Khaldun himself, Jabir Ibn Hayyan, Al-Khawarizmi, Al-Kindi, Abu Bakr al-Razi, Ibn al-Haitsam, Ibn Sina, AlBiruni , and Ibn Nafis. But the dichotomy that occurs continues to spread and widen, so that it becomes an unfavorable condition for the development of science in Islam (Hidayatulloh, 2017).

Muslim scholars study, the decline of science in the Islamic world is caused by two factors; internal and external. Among internal factors is that the Islamic ummah is closer to the understanding of Jabariyah, which is more fully accepting of destiny. This understanding was supported by al-Ghazali. When in power, Muslims are fast complacent, and less innovative in extracting knowledge, especially in the eighth immortal. The external factor is the invasion of the Islamic world which caused the Muslims to experience defeat. One of the biggest is the collapse of Baghdad as one of the empires of the Islamic world civilization due to the Mongol attacks, which became prolonged and made it difficult for Muslims to rise again. Besides the transfer of centers of scientific activities from the Islamic world to Europe (Kosim, 2008; Munir \& Ismail, 2008).

There are at least four problems due to the dichotomy of general sciences and religious sciences. First, the emergence of ambivalence in the Islamic education system. Second, the gap between the Islamic education system and Islamic teachings. An ambivalent education system reflects the dichotomous view that separates the Islamic religious sciences and general sciences. Third, the disintegration of the Islamic education system, where each system (modern/general) Western and Islamic still insisted on maintaining its existence. Fourth, the emergence of inferiority in managing Islamic educational institutions (Bisryi, 2009; Mustaqim, 2015). This is due to the fact that the Western education system which in reality does not value cultural and moral values has been used as a benchmark for the progress and success of the nation's education system (Jamil, 2015; Nurullah, 2008; Sahin, 2018).

Efforts towards true scientific integration have begun since the 9th century, despite the ups and downs. During Al-Farabi's time (Haq, 2011), the notion of the unity and hierarchy of knowledge, which emerged as a result of traditional inquiry into epistemology, and was the basis for investigation and research, seemed to flourish and take its place at that time. No matter which channel, human knowledge seekers get that knowledge (Birdişli, 2017; Sparavigna, 2014).

Al-Farabi is known as one of the Islamic figures who pioneered the integration of science. According to him, education must be able to guide individuals to perfection, because humans are created to reach perfection. The highest perfection is happiness. So, education must be able to give birth to happiness for those who are in it. Perfect humans are people who understand the virtues that give birth to happiness and carry it out in everyday life. Al-Farabi emphasizes education that combines theoretical abilities with practical actions in real life. Simply put, Al-Farabi believes science will become perfect when it is understood and practiced in real life. The expected educational outcomes are scientists who have morality, intelligence and good morals (Khoirudin, 2017; Setiyawan, 2016).

Ibn Taymiah and Ibn Hazm are also known as figures who integrate science and religion. Both are known by the modern scientific method of induction as a complement to the method of deduction which was first known to tend to be speculative. Logical (burhani) or rational methods are often used to test whether something is considered right or wrong from 
the results of inferences based on deduction or quantitative methods. This method is also known as syllogism (al-Qiyas). There are also intuitive (irfani) methods. This method reveals the secrets of existing reality, through the relationship between the human heart and God, one form is to cleanse yourself from the dirt of $\sin$ and selfishness. Combining rationality with cleanliness of heart as a servant of God. Almost no different from AlFarabi which emphasizes the integration of mastery of science and emphasis on morals (Akbarizan, 2014).

As one of the foundations in Islam, the Qur'an is not about dichotomy, but rather the head of integration. The command in the Qur'an to think of all His creations is universal, not dichotomous. What is created by God, can be understood more closely, in more detail with the use of science and science. The more modern, the more detailed the understanding of people towards God's creation. The command to prosper the earth and use science for good is also universal and integral, there is no dichotomy. So that science which has been considered ansich science, basically is part of the science demanded by God to be understood and mastered by the Islamic Ummah (Charles, 2011).

In Indonesia, the effort to integrate science and religion has started especially since the establishment of Islamic tertiary institutions which open departments not only in religion, such as sharia, tarbiyah, da'wah and others. But also these Islamic tertiary institutions have dared to open faculties and general science study programs, such as politics, economics, even medicine and so on (Batubara, 2018). The emergence of State Islamic Universities (or Universitas Islam Negeri/ UIN) in Indonesia such as UIN Maulana Malik Ibrahim Malang, UIN Syarif Hidayatullah Jakarta, UIN Sunan Kalijaga Yogyakarta, UIN Sunan Gunung Djati in Bandung, West Java and UIN Syarif Qosim Pekanbaru-Riau, followed by many Islamic universities in Indonesia. And interestingly, from time to time, the number of students from Islamic educational institutions is increasing. Likewise, the accreditation of institutions is increasing. The trend to develop integrative science between Religion and general science is increasingly loved by Muslims in Indonesia (Muslih, 2016).

The number of Islamic tertiary institutions leading to the integration of science, invites the question, does each country with a Muslim majority population have the same pattern in applying science integration to universities, or has a different model? This research was carried out to photograph on a more macro scale, Southeast Asia, by comparing models of the integration of science in higher education in Malaysia and Indonesia.

\section{METHOD}

The issue of scientific integration in the realm is not new in the academic world, either at the level of a thesis, thesis or dissertation. Since the echo of the Islamization of science by Ismail Raji alFaruqi in the 80 s, to the formation of Islamic higher education institutions based on scientific integration through the transition of the status of IAIN and UIN in Indonesia in the 2000 s to the present, as well as a number of dynamics of changing models. Islamic education in the Southeast Asian region, there are quite a lot of studies on scientific integration. Given the limited space for discussion, some related research will be discussed. As far as the research team observes, research and writings related to this issue are only limited to aspects of the philosophy of science from various scientific perspectives and their relationship with various local scale cases.

Norazmi Anas et al wrote a study entitled The Integration of Knowledge in Islam: Concept and Challenges. The discussion on scientific integration is directed at finding the right concept in facing the challenges of social realities in Malaysia. It is feared that the secularization of knowledge that occurs in Malaysia will have a social impact on society, in the form of a further distance from the community from their Islamic identity. This is also the background for the research of Norazmi Anas et al. 
however, the case faced by Malaysia in this case certainly has relevance to the situation in Indonesia in particular and Southeast Asia in general. In this case, this research can certainly contribute a number of data for the analysis related to the prospects for integration and the challenges that will be explored in this study.

Likewise, the Axiology on the Integration of Knowledge, Islam and Science written by Mas'ud Zein from UIN Suska, which tries to measure the integration of science in axiological perspective. In relation to this research, it is clear that axiological aspects cannot be avoided in this research, especially the discussion regarding the question of why a science is deemed necessary and how to use it in the context of scientific integration. Another article that analyzes Integration to Scientists is Sudarman's writing entitled Development of Paradigmatic Integratic Patteren at Fathoni Thailand University, this article portrays the scientific integration model applied at Fathoni University. One of the advantages of this article is the ability to describe and analyze the integration model between naqli (modern) science and religious science (revelation)(Sudarman, 2018) .

The difference between this article and previous research and articles is in the context of comparing the existing models of integration of science and religion in Indonesia and Malaysia. The two countries are the object of research because these two countries are very concerned about integrating religion and science.

\section{RESULT AND DISCUSSION}

Models of integration of science and Islam can be seen in Southeast Asia in Indonesia and Malaysia. Two countries with a majority Muslim population. In both countries, the model of integration of science and Islam can be seen in two large universities, namely IIUM in Malaysia and UMM in Indonesia. In the two universities established by the two Islamic organizations, integrating science and Islam. IIUM was founded by the Organization of the Islamic
Conference (OIC), while UMM was founded by the Muhammadiyah organization.

\section{History, foundation, and application of the integration of science integration in International Islamic University Malaysia}

IIUM initially sponsored by eight countries which are members of the Organization of the Islamic Conference (OIC). The establishment of this university is to realize the idea of an international Islamic education institution, about the Islamization of science. The university is based on Islamic teachings, but non-Muslim students are also accepted as students. The university is trying to integrate Islamic science with humanities sciences.

This university successfully combines modern scientific disciplines professionally with traditional and moral values. IIUM students come from various countries, representing almost all countries in the world. The university builds the characteristics and foundation of science (the foundation of knowledge) so that it appears as a university with the best excellence in the integration of Islam and science (the integration of knowledge). The International Islamic University of Malaysia appears to carry the paradigm of scientific integration as the best choice, both in Malaysia and other countries. The university is trying to integrate science and Islamic sciences. Although this university is based on Islamic teachings, non-Muslim students are also accepted as students. Since its inception, English was instead used as a medium for teaching and managing education administration.

Thoughts about the integration or Islamization of science at the International Islamic University of Malaysia appear to be in totality in the midst of the hectic global world that is laden with advances in science and technology. With a concept of integration in the context of transforming and absorbing actual knowledge in the context of understanding revelation, or being able to understand revelation in developing science. The process of integration of knowledge or Islamization of knowledge is nothing but the 
process of returning or refining existing knowledge to the essential concept of monotheism, the unity of the meaning of truth and the unity of sources. From these three processes, axiology (objective), epistemology (methodology) and ontology (object) of science are derived in the teaching and learning process at the International Islamic University in Malaysia.

In terms of axiological, science and technology must provide the maximum benefit for human life. That is, science and technology become important instruments in every development process as an effort to realize the benefit of human life as a whole. Thus, science and technology must provide the maximum benefit for human life. To achieve this goal, an effort is needed to integrate Islamic sciences with science and technology at the International Islamic University of Malaysia. The implication is that a balanced integration will be achieved between progress in the fields of science and technology with progress in the fields of Islamic science, morals and ethics.

The framework of thought regarding scientific integration (Islamization of science) at IIUM is influenced by the thinking of Naquib Al-Attas (Smart, 1986) and Ismail Raji'Al-Faruqi (Zuhduyah, 2017). This is inseparable from Islamic awareness in the midst of the global world struggle which is full of advances in science and technology. There are several foundations in building scientific integration at IIUM, namely (1) Theological-normative foundation. How to understand something using teachings that are believed to come from God, and are absolute. Al-Qur'an and Al-Sunnah do not differentiate between Islamic sciences and sciences (science-technology and social humanities); (2) Philosophical foundation. The combination of Islamic science and science is expected to be able to understand the complexity of human life; and (3) Sociological foundation. This sociological foundation that science is able to solve social problems in the context of the paradigm of scientific integration.
Science is knowledge that is collected by scientific methods (scientific methods). In another explanation, science is a collection of systematic knowledge, which is built through experimentation and observation. In other words, science will only be realized if it is cultivated, developed, and developed. Knowledge will not be born by doing nothing. Science is precisely the truth of science is "it's not final truth". Science is not a revelation (holy book) whose truth is final and absolute. Science, therefore, is not an eternal monument, which has been patented and may not be reviewed. Science (knowledge) is a continuous process, "will never end" (a never ending journey), it will continue and always proceed as long as this life exists (Junaedi, 2014).

A unique effort to make knowledge (knowledge), so that it remains relevant to the times, is the development of science itself. This is coherent with Islamic science. In this context, scientific integration is necessary to the maximum. IIUM has broken through in breaking the dichotomy by carrying out the integration of knowledge. In the development of science in general can be classified into three strategies as follows: (1) Science is developed from the context or closed to science with the motto "science for the sake of science only". In this context scientists are in ivory towers and have no effect on anyone and what is in society. So what happens is that the values of communalism, universalism are nothing more than endless boundaries and constraints. (2) The science of melting in context, thus science tends to change sometimes into an ideology perpetuated to the achievement of certain goals, with the motto of assimilation, integration, adaptation, and tolerance. (3) Science and context influence each other, complement and need each other. In this context there is a functional relationship between science, ethics, religion, art, and even intertwining with one another. This context upholds "science for the sake of human progress," as its trademark.

This model seems to support the development of Islamic science as a whole and consistently. This strategy for developing Islamic science must remain based on the 
philosophy of science, with three pillars supporting science, namely ontology, epistemology, and axiology. In addition to the philosophical basis for the development of Islamic sciences, which must also be considered in an operational aspect, namely the application of Islamic scientific theories in the practical empirical world in society (Aminnuddin, 2020; Mohammed et al., 2013; Sabic-El-Rayess, 2020).

The application of scientific integration at IIUM strengthens in this context, although it requires maximum effort in building the integration of knowledge. In the development of science, Islam actually laid a strong foundation. Islam makes science a condition of worship. Islam highly praises those who diligently seek knowledge, because in Islam science is called the light of truth and is believed to be the key to the success of the world and the hereafter. There is no dichotomy in the development of science.

Many experts consider that the history of human civilization has never known any religion that pays such great and perfect attention to science other than Islam. So the principle, Islam really appreciates science by continuing to correct the ways or methods that are considered wrong in exploring the knowledge. Intellect functions as a medium or a tool to explore knowledge (Hj Othman, 2015; Shah et al., 2016).

Science always undergoes renewal and improvement in accordance with the rules or norms, which adapt to the progress of the times. Science is always between those who are less than perfect, those who are blurred to be clear, those who are divorced, are becoming integrated, those who are wrong are becoming more right and those who are still figuring are becoming more convinced. Unlike the matter of faith and belief, which is taught in the books of the faith, it is not proper to adjust to the problems of science. Every time a new problem arises in the world of science in a human generation, it is not fitting for Muslims to try to interpret or show from the scriptures the details of what has been obtained in that science (Galadari, 2011; Pabjan, 2016; Spencer, 1989).
The integration of knowledge appears as an attempt to create knowledge based on Islamic values, but apart from the influence of science in the West. It appears as an effort to build a scientific paradigm based on Islamic values, both ontologically, epistemologically, and axiologically. So, actually implementing the integration of knowledge at IIUM or Islamizing science is not a confrontational step towards the development of science that has developed today. Islamization of knowledge means to refine knowledge or restore the essence of science itself. Because as stated by historians that Western civilization today which is considered to have succeeded in developing science actually initially learned from Islam.

The paradigm of the integration of science at IIUM appears to be a certain perspective or a particular approach to unifying science. In this context, sticking out as an integrative science integration paradigm or in short, an integrative science integration paradigm, in terms of views that see something as part of the whole science. Religion and science are different in some ways, but in some ways, they have something in common. Religion emphasizes morality and preserves traditions that are already established (ritual), tend to be exclusive, and subjective. While science is always looking for new things, it is not very much related to ethics, progressive, inclusive, and objective. Although religion and science are different, they have something in common, which aims to provide peace and convenience for humans. There are at least two main reasons for the weakness of this approach. First, the different scientific roots between the religious sciences and general sciences. Secondly, the modernization and Islamization of science through curriculum and institutions, although carried out with the aim of creating integralism and integration of Islamic and general science, will always leave scientific dichotomy. This was hacked at the International Islamic University of Malaysia in developing the integration of knowledge. This becomes the challenge (challenge) in developing scientific knowledge as an institution. 
Thus, the paradigm of integration of Islamic sciences and general sciences at the International Islamic University of Malaysia, emerged as a form of concern for some Muslim thinkers about the very dominant global threats and challenges. Especially the view of Western scientists, so Muslims must save their religious identity and authority. In this context, IIUM then plays a role in taking the opportunity to apply the integration of knowledge in the development of science.

\section{History, foundation, and application of the integration of science integration in Universitas Muhammadiyah Malang}

Universitas Muhammadiyah Malang (UMM) was established in 1964, at the initiative of leaders and leaders of the Malang Regional Muhammadiyah. In the thirty-year span of UMM's journey (1964-1994), the most significant developments began in the 1983s. Since then, UMM has recorded very impressive developments, both in the field of improving the status of study programs, in improving administration, adding campus facilities and facilities, as well as adding and improving the quality of its management staff (administrative and academic).

UMM students from all provinces and more than 10 countries have very diverse backgrounds, ranging from social status, economy, religion, ethnicity, and culture. UMM which has the motto "From Muhammadiyah to the Nation" already has a commitment to organize high quality education that can be enjoyed by all groups. The students came with extraordinary enthusiasm and energy to study at UMM in order to achieve the goals and interests that were originally intended. Both personal interests, interests in developing the country, or even other interests that have been clearly planned by students and their families. For this reason, they seek universities with resources that enable them to realize their goals. At UMM, students find lecturers, employees and fellow friends to share in the joys and sorrows during their studies until a lasting friendship is established.
The commitment of UMM not only produces graduates who have good academic abilities, but also upholds the ethical values of living in society, and acts Islamic. This can be achieved, because students on the UMM campus will be accompanied by lecturers and all staff who will educate seriously, sincerely, sincerely and use their hearts through the use of complete facilities and the education system that is already running well.

In 2013, when the government through the Higher Education National Accreditation Agency (BAN-PT) assessed various campuses throughout Indonesia, UMM was one of the eight earliest universities to achieve accreditation A. From 2008 to 2018, UMM became the best private campus in East Java, so entitled to award Excellence Campus Award (AKU) 10 times and AKU Kartika Award four times from Kopertis VII. While at the global level, UMM in the middle of 2016 had just become an Associate Member of ASEAN University Network-Quality Assurance (AUN-QA). Previously in 2012 UMM also had won 2 stars from the worldfamous campus ranking institutions QS Stars University Ranking, in particular UMM won 4 stars in infrastructure.

Muhammadiyah's education areas, including Islamic, nationality, wholeness, togetherness and excellence, are integral entities that should be developed in every Muhammadiyah educational institution. Why is Islam placed first? Because, so far one of the most prominent characteristics of Muhammadiyah's education is the field of Islamic religion. Through the world of education, Muhammadiyah included its "enlightenment mission" to the general public. With this character, there are no Muhammadiyah educational institutions that do not teach the subjects of Al-Islam and Muhammadiyahan (AIK). In the context of higher education, as well as at UMM, according to (Bahtiar, 2018), if in terms of the AIK curriculum it becomes part or sub, then in the status of Muhammadiyah higher education it is declared as a soul and foundation. "Muhammadiyah universities, hereinafter referred to as (Perguruan Tinggi Muhammadiyah/ PTM), is a Muhammadiyah 
charitable endeavor in the field of higher education that is imbued and based on the values of Al-Islam and Kemuhammadiyahan at the ideological-philosophical as well as practical-applicative levels and is one of the strengths for Muhammadiyah's sustainability and sustainability in achieving its goals as a missionary and tajdid movement across the ages."

Muhammadiyah is an Islamic renewal movement engaged in education, health, economics, and community empowerment (Elhady, 2017; Nashir, 2015; Shokheh et al., 2018). Reforms in the field of education have been carried out by Muhammadiyah through three things, first the curriculum. Muhammadiyah's education teaches religious studies and general studies as well, secondly, the renewal of learning methods from the classical-modern paradigm, thirdly, institutional renewal is a combination of the pesantren and school system. This renewal will certainly continue to dynamically follow the changing times that are fast paced (Nuryana, 2019).

The direction and foundation of science integration at UMM is contained in the university's vision and mission. The vision of UMM is "In 2030 becoming a leading University in the development of science, technology, and art based on Islamic values". Meanwhile, the UMM Mission, namely (1) Organizing education and learning in a professional manner based on research and development of science and technology; (2) Conducting research that contributes to the development of science and technology; (3) Organizing research-based community service to improve community welfare; (4) Cooperating with other parties that are mutually beneficial; (5) Organizing guidance and development for the academic community based on Islamic and Kemuhammadiyahan values; and (6) Organizing university institutional management professionally based on Islamic values.

The "leading" statement implies that UMM and all academicians will be able to produce creative and innovative work through the management of the 2019-2030 UMM
Development Master Plan and the development of quality-based higher education institutions and mastery of science, technology and art in Industrial Revolution 4.0 that is consistent and continuous. Thus every step and activity of UMM activities must produce an impact on outcomes and achievements that have competitive advantages at national and international levels. The statement "prominent" also means that UMM can be an example in the management of educational institutions as well as having superior academic community who have various roles in society and nation. The statement "development of science and technology" implies that UMM as a provider of tertiary education always develops innovative education and teaching through the use of information technology such as operational technology, internet of things, and big data analysis that can improve the ability of the UMM academic community in new literacy including data literacy, technological literacy as well as human literacy. Then UMM always reconstructs higher education policies that are adaptive and responsive to the Industrial Revolution 4.0 which include the development of reliable human resources, trans-scientific disciplines, and various research breakthroughs. Increasing the ability of new literacy will sustain the formation of entrepreneurial spirit. The statement "Islamic values" means that Islamic values are used as a guide in the development of science and technology through educational activities, research, community service, and Al-Islam and Kemuhammadiyahan (AIK). One of the values of Islam that has been determined in the form of ethical behavior, namely: (1) shiddiq, (2) trust, (3) tabligh, (4) fathonah. The four values of ethical behavior are the foundation of the development of human literacy that has a humanist, multicultural, communicative, and creative nature (Rencana Induk Pengembangan Periode 2019-2030, 2019).

Based on this it is very clear that UMM is a representation of the Muhammadiyah movement that integrates the disciplines of science and Islam, as a continuation of the ideas of $\mathrm{KH}$ Ahmad 
Dahlan (founder of Muhammadiyah) who since 1920 wanted integration between science from the West and Islam. UMM together with a number of other Muhammadiyah universities since developing scientific disciplines and curricula that are integrated with Islamic concepts with the aim of science provided are more beneficial for life. Integration requires huge energy, from road maps, studies, to human resources, by among others criticizing secular science from the West by using Islamic concepts to making comparisons between the two at the empirical level. Therefore, collaboration between universities that have concerns about it is absolutely necessary, in addition to being a vehicle for enriching best practices.

UMM has declared that education which is managed with all its instruments, including in this case the development of science and technology, is directed to become an alive education. Education that can overcome the problems facing humanity. As long as education is not directed towards dealing with human problems, then education will not be of much use.

This pattern of irrigation in practical records has better relevance, quality and competitiveness. The dichotomy of scientific sciences basically is not a significant problem for UMM. This is as if it is not a problem in the General Higher Education environment hat breathes Islam like UMM, which since its establishment has already had a faculty of religion and general (Yunus, 2014).

The framework of thought regarding scientific integration at UMM is also exactly the same as IIUM, also influenced by the thoughts of Naquib Al-Attas (Smart, 1986) and Ismail Raji'Al-Faruqi (Zuhduyah, 2017). The founding fathers and managers of UMMand of course also the Muhammadiyah Central Leaders-cannot be separated from Islamic awareness in the midst of a global world struggle that is laden with advances in science and technology. In addition, based on the results of observation, UMM tends to use the integration and interconnection paradigm introduced by M. Amin Abdullah. According to (Muttaqin, 2018), This approach generally consists of first, efforts to develop Islamic science curriculum must integrate not only Islam and natural science but also humanities social science. Second, based on the contextual education paradigm, the Islamic science curriculum must consider the context and culture of the Indonesian nation. This aim is to transfer knowledge and solutions into real problems in life.

\section{CONCLUSION RECOMMENDATION}

AND

Science integration has begun to be widely practiced and continues to be developed by higher education institutions in Southeast Asia, including Indonesia and Malaysia. Science integration carried out by Islamic universities in Indonesia and Malaysia applies an inclusive education model. An open and universal education. Along with the spirit of global development. Islamic higher education no longer limits the study program to religious science alone, but also general science, including omitting the terms and designations of religious and general science. Furthermore, it accepts cross-national and cross-religious students. As happened at the Universitas Muhammadiyah Malang and the International Islamic University of Malaysia. Its application makes higher education institutions increasingly develop and continue to advance. This model needs to be supported and backup by the government in the future, the integration of science in higher education, so that education based on religion is truly inclusive, advanced and modern.

\section{REFERENCES}

Ahmed, R., \& Segerson, K. (2006). Emissions Control and the Regulation of Product markets: The case of Automobiles (Working Paper, Department of Economics, Issue July).

Akbarizan, M. (2014). Integrasi Ilmu: Perbandingan Antara UIN Suska Riau dan Universitas Ummu Al Quran Makkah (M. A. Almaktsur, Ed.). Suska Press. 
Aminnuddin, N. A. (2020). Dataset on Islamic ethical work behavior among Bruneian Malay Muslim teachers with measures concerning religiosity and theory of planned behavior. Data in Brief, 29, 105157.

Bahtiar, A. P. (2018). AIK dari Ciri Khas ke Asas Pendidikan Muhammadiyah: Proposal Untuk Merumuskan Sistem Pendidikan Muhammadiyah. Seminar Nasional Al-Islam Dan Kemuhammadiyahan, 1-9.

Batubara, H. H. (2018). Metode dan Model Integrasi Sains dan Islam di Perguruan Tinggi Agama Islam.

Birdişli, F. (2017). Theoretical Background for a Safe Eurasian Integration: Al Farabi's World State Theory. Proceeding of Eurasian Forum for Social Science, November 2014, 1-18.

Bisryi, H. (2009). Mengakhiri Dikotomi Ilmu Dalam Dunia Pendidikan. Edukasia Islamika, 7(2), 181-194.

Charles, C. (2011). Integrasi Ilmu dengan Agama untuk Mengangkat Harga Diri Pelajar Muslim. Annual International Conference on Islamic Studies, 21682185.

Dahlberg, K. (2013). Guest editorial: The scientific dichotomy and the question of evidence. International Journal of Qualitative Studies on Health and Well-Being, 8(1), 6-8.

Dallal, A. S. (2018). slam without Europe: Traditions of Reform in EighteenthCentury Islamic Thought (Islamic Civilization and Muslim Networks). In Islam without Europe. University of North Carolina Press.
Elhady, A. (2017). Islamic Reform Movement In Indonesia: Role Of Muhammadiyah In Social Empowerment. International Journal of Academic Research in Business and Social Sciences, 7(8), 340-350.

Galadari, A. (2011). Science vs. Religion: The Debate Ends. The International Journal of Science in Society, 2(2), 110.

Haq, S. N. (2011). Al-Farabi. The History of Western Philosophy of Religion: Medieval Philosophy of Religion, 2(1), 47-60.

Hidayatulloh, H. (2017). Realasi Ilmu Pengetahuan Dan Agama. Proceedings of the ICECRS, 1(1), 901-908.

Hj Othman, M. Y. (2015). Appreciation of Science in Al-Qur'an. Academic Journal of Interdisciplinary Studies, 4(3), 89-96.

Jamil, R. (2015). Agents of American hegemony in management education: Evidence from Malaysia. International Journal of Management Education, 13(3), 302-315.

Junaedi, M. (2014). Madrasah: Dari Nizamiyah hingga Pesisiran Jawa. Nadwa, 8(1), 95-124.

Khoirudin, A. R. (2017). Pemikiran Abu Nasr Muhammad Al-Farabi tentang nilainilai pendidikan kepemimpinan negara utama. PROFETIKA, Jurnal Studi Islam, 18(2), 139-149.

Kosim, M. (2008). Ilmu Pengetahuan Islam (Perspektif Filosofis-Historis). Jurnal TADRIS, 3(2), 121-140.

Maussen, M., Bader, V., \& Moors, A. (2011). Colonial and Post-Colonial 
Governance of Islam: Continuities and Ruptures. In IMISCOE Research. Amsterdam University Press.

Mohammed, A. S. A., Tibek, S. R. H., \& Endot, I. (2013). The Principles of Total Quality Management System in World Islamic Call Society. Procedia - Social and Behavioral Sciences, 102(Ifee 2012), 325-334.

Munir, G., \& Ismail, S. M. (2008). Warisan Intelektual Islam Jawa: Dalam Pemikiran Kalam Muhammad Shalih As-Samarani. Walisongo Press.

Muslih, M. (2016). Tren Pengembangan Ilmu di Universitas Islam Negeri Maulana Malik Ibrahim Malang. Teosofi: Jurnal Tasawuf Dan Pemikiran Islam, 6(1), 220-247.

Mustaqim, M. (2015). Pengilmuan Islam dan Problem Dikotomi Pendidikan. Jurnal Penelitian, 9(2), 255-274. https://doi.org/10.21043/jupe.v9i2.132 1

Muttaqin, A. (2018). Konstruksi Kurikulum Sains Islam Keindonesiaan (Integrasi Islam, Sains Kealaman, Sains Humaniora Dan Keindonesiaan). EDUKASI: Jurnal Penelitian Pendidikan Agama Dan Keagamaan, 16(1), 80-93.

Nashir, H. (2015). Muhammadiyah a reform movement. Muhammadiyah University Press.

Nurullah, A. S. (2008). Globalisation as a Challenge to Islamic Cultural Identity.

The International Journal of Interdisciplinary Social Sciences: Annual Review, 2(6), 45-52.

Nuryana, Z. (2019). Muhammadiyah Dan Pendidikan Di Indonesia.
Pabjan, T. (2016). Some remarks on the conflict between faith and science. The Person and the Challenges. The Journal of Theology, Education, Canon Law and Social Studies Inspired by Pope John Paul II, 6(1), 67. https://doi.org/10.15633/pch.1658

Putnam, H. (1966). What Theories are Not. In Studies in Logic and the Foundations of Mathematics (Vol. 44, Issue C). Board of Trustees of the Leland Stanford Junior University.

Sabic-El-Rayess, A. (2020). Epistemological shifts in knowledge and education in Islam: A new perspective on the emergence of radicalization amongst Muslims. International Journal of Educational Development, 73(102148), 1-10.

Sahin, A. (2018). Critical issues in islamic education studies: Rethinking islamic and western liberal secular values of education. Religions, 9(11), 1-29.

Setiyawan, A. (2016). Konsep Pendidikan Menurut Al- Ghazali dan Al-Farabi (Studi Komparasi Pemikiran). Tarbawiyah Jurnal Ilmiah Pendidikan, 13(1), 51-72.

Shah, Mohd., Panjwani, F., Dajani, R., Ghaly, M., Drees, W., Clayton, P., Golshani, M., Guessoum, N., Altaie, M., AlAkiti, A., \& Zorlu, T. (2016). Islam and Science: Muslim Responses to Science's Big Questions (U. Hasan \& A. Osama, Eds.). Muslim World Science Initiative.

Shokheh, M., Ebrahimi, M., \& Yusoff, K. (2018). From Islamic Teaching to Social Charity: The Muhammadiyah Movement in Semarang, Central Java, 
Indonesia; 1926-1940. Asian Culture and History, 10(2), 58.

Sing, M. (2017). The Decline of Islam and the Rise of Inhitạaț: The Discrete Charm of Language Games about Decadence in the 19th and 20th Centuries. In The Sultan's Anthologist-Ibn Abi Hagalah and His Work (Issue April).

Smart, N. (1986). Islam, secularism and the philosophy of the future: Syed Muhammad Naquib al-Attas (Mansell Publishing Company, London, UK and New York, USA, 1985). Futures, 18(6), 828-829.

Sparavigna, A. C. (2014). The Ten Spheres of Al-Farabi: A Medieval Cosmology. International Journal of Sciences, 3(6), 34-39.

Spencer, N. ; (1989). "Science and Religion": The perils of misperception. Theos.

Sudarman, S. (2018). Development Of Paradigmatic Integratic Pattern At Fatoni Thailand University. Jurnal Adabiyah.

Tan, C. (2017). Colonialism, Postcolonialism, Islam, and Education. In D. H. \& A. R. (Eds.), Handbook of Islamic Education. International Handbooks of Religion and Education (Issue
September, pp. 1-12). Springer, Cham.

Umar, M. S. (2005). Islam and Colonialism: Intellectual Responses of Muslims of Northern Nigeria to British Colonial Rule. In Islam in Africa (pp. 1-298). Brill.

Rencana Induk Pengembangan Periode 20192030, 1 (2019).

Wallerstein, I. (1999). Islam, the west, and the world 1. 2(October 1998), 109-125.

Yunus, M. (2014). Integrasi Agama Dan Sains: Merespon Kelesuan Tradisi Ilmiah Di Ptai. INSANIA: Jurnal Pemikiran Alternatif Kependidikan, 19(2), 284-313. https://doi.org/10.24090/insania.v19i2. 717

Zuhdiyah, Z. (2017). Islamisasi Ilmu Ismail Raji Al-Faruqi. Tadrib: Jurnal Pendidikan Agama Islam, 2(2), 293313. 